\title{
The Chemical Properties of Soils from Forest Fields Occupied by Oil Drills in Moinesti, Romania
}

\author{
CRISTINEL CONSTANDACHE, LUCIAN CONSTANTIN DINCA, CIPRIAN TUDOR* \\ "Marin Dracea" National Institute for Research and Development in Forestry, 128 Eroilor Blvd., 077190, Voluntari, Romania
}

\begin{abstract}
Forest fields temporary occupied by different industrial activities are restored to the silvicultural circuit after the industrial activity has ended. These fields should be apt for reforestation and should have admissible values regarding their content of dangerous substances. The present article describes and interprets the characteristics of soils from four fields occupied temporary by oil wells in Moineşti, Bacău County. The content of clay, soluble salts and nutritive elements were analysed, together with the soil's reaction, the content of hydrocarbons or other soil characteristics. The admissible values for installing, growing and developing forest species were then emphasized. The obtained results have illustrated the fact that the oil extraction activity had negative effects on soils, namely: a strong consolidation (especially on access roads); the truncation and/or derangement/mixture of horizons or soils stratums with the rock; depletion of nutritive substances; salinization, argilisation and pollution with oil residues. In order to render these fields back to the silvicultural circuit, bio remedy technologies must be applied or other measures that can eliminate the pollutant from the soil (decontamination methods), followed by pedoameliorative measures.
\end{abstract}

Keywords: forestry soils, pollution, oil residues

\section{Introduction}

The oil drilling activity has required the temporary occupation (tens of years) of fields from the national forest fund (removed from the silvicultural circuit) and the placement of drills (bore). After the drills are closed (deactivated), the fields are rendered back to the silvicultural circuit (based on current legislation) and require afforestation works. As such, documentation works were realised during 20192020 for the reintroduction in the silvicultural circuit of 33 fields from all over the country occupied by abandoned drills [1].

In order to be afforested, the fields must meet the biological requests of forest species from that certain area and must be situated within the admissible limits for the level of pollutants or other dangerous elements. In the majority of cases, a series of additional works are necessary such as remediation, decontamination or soil improvements, based on the content of dangerous elements from the soil. These are followed by special silvo-ameliorative works [2].

Soil pollution with oil hydrocarbons or with other products used in the oil extraction process represents a problem with a major risk for human health as well as for the environment. Total oil hydrocarbons are related to analytic results and the impact on the human and environment health. The negative effects of these hydrocarbons on the soil consist in the obstruction of water circulation and gas exchange due to the waterproof layer created by these compounds. This leads to root suffocation phenomenon and to the apparition of depletion processes [3]. As the soil's internal medium becomes anaerobic, the number and metabolic activity of bacteria and microorganisms steadily decreases. The presence of oil hydrocarbons in soils affects seed germination, the growth of forest seedlings and obstructs their normal development during the vegetation season. Hydrocarbons can penetrate seeds and kill the embryo or can affect germination by reducing the water flux towards the seeds or the oxygen necessary for germination [3].

*email: cipriantudor95@yahoo.com 
At the worldwide level, several ecosystems from Brazilian territory, were deeply affected by the content of oil located in sediments and organisms, being registered a high presence of degradation. Due to the Brasilian coastal waters, the mangrove community suffered a lot of structural transformations and malformations of roots, leaves and fruits, caused by the inputs of oil [4].

The polluted environments with oil, during the biodegradation of the petroleum hydrocarbons, are characterized by lower temperatures, strongly acidic or alkaline $p \mathrm{H}$, high pressure or high salt ratio, manifested in the microstructure of the soil. After the Gulf War in 1991, the bioremediation method was tested in several studies for reduction or to treat the remaining sites polluted by oil spills, in the Arabian Gulf western coast and in Kuwaiti desert [5].

In north-eastern Poland, pollution with petroleum occurred in August 2005, on lands with fuel tanks located underground. The pollution of clay soils with diesel oil, produced changes in microstructure, by loosing important clay particles with detachment from the surface, degradation of amount of clayey microaggregates, density of pores and clay particles deformation on edges and corners [6].

In the Amazonian Tropical Rainforest of Ecuador, the petroleum pollution damaged large areas from this region, especially Euphorbiaceae, Fabaceae, Melastomataceae, Rubiaceae plant families that had registered an lower content of chlorophyll in the leafs, comparing with the unpolluted areas [7].

On the other hand, the soluble salts or clay content as well as the lack of certain mineral or nutritive soil elements are limitative factors for the installation, growth and development of most forest species $[8,9]$. In this way, the reintroduction of fields in the silvicultural circuit is tedious.

The content of these elements determines the works and measures necessary for the soil's decontamination or bio-remedy [10,11]. This is followed by the establishment of mandatory silvoameliorative works without which the reinstallation of forest vegetation could not be possible [12,13].

Based on the field observations and the results of the physico-chemical analyzes of the soil from the affected areas, their characteristics were briefly exemplified in order to determine their favorability for the resettlement of forest vegetation $[8,13]$. The obtained results highlight the nature and intensity of soil degradation and pollution processes.

\section{Materials and methods}

Four fields from Moineşti oil area were studied in total. They all contained oil drills that were deactivated (abandoned): 6502 Taşbuga drill, 1137 Moineşti city drill, 310 Asău drill and 145 Lucăceşti drill. The fields are located in the afforested mountain area from Bacău County, managed by Bacău Forest District described in Figure 1 [14], respectively in the middle area of the Eastern Carpathians, at altitudes between 600 and $1000 \mathrm{~m}$, with the lithological substrate formed by sandstones, marls, clays and their alternations.

In order to emphasize soil characteristics, 2-4 representative soil profiles were realized, from which 1-3 were executed within the surface (bore), at a distance of $25-30 \mathrm{~m}$. A soil profile (named witness profile - ex. P5M) was created in the forest bordering the bore with the purpose of emphasizing the physico-chemical changes of the soils from drill fields. The profiles were executed at a depth of approximately 60-80 cm (the rock layer being present under this depth). The samples were taken from layers with a depth of $20-25 \mathrm{~cm}$ in order to appreciate better the soil characteristics and implicitly, the changes created on the profile. This method was applied especially where the depth of a layer exceeded $25 \mathrm{~cm}$. In this way, we could verify if the field's soil has suffered changes in composition and structure. Two-three soil samples were gathered for each profile.

The soil samples taken from drill fields or from neighboring fields were analyzed from a physicochemical perspective in the Eco-pedology Analysis Laboratories from INCDS "Marin Dracea" (Voluntari and Brasov). The following elements were determined: $p \mathrm{H}$, the content of humus, carbonates, nitrogen, mobile phosphorus, mobile potassium, soluble salts and granulometric fractions [15-17]. All the other physical properties (structure, compactness, color) were determined organoleptically. 


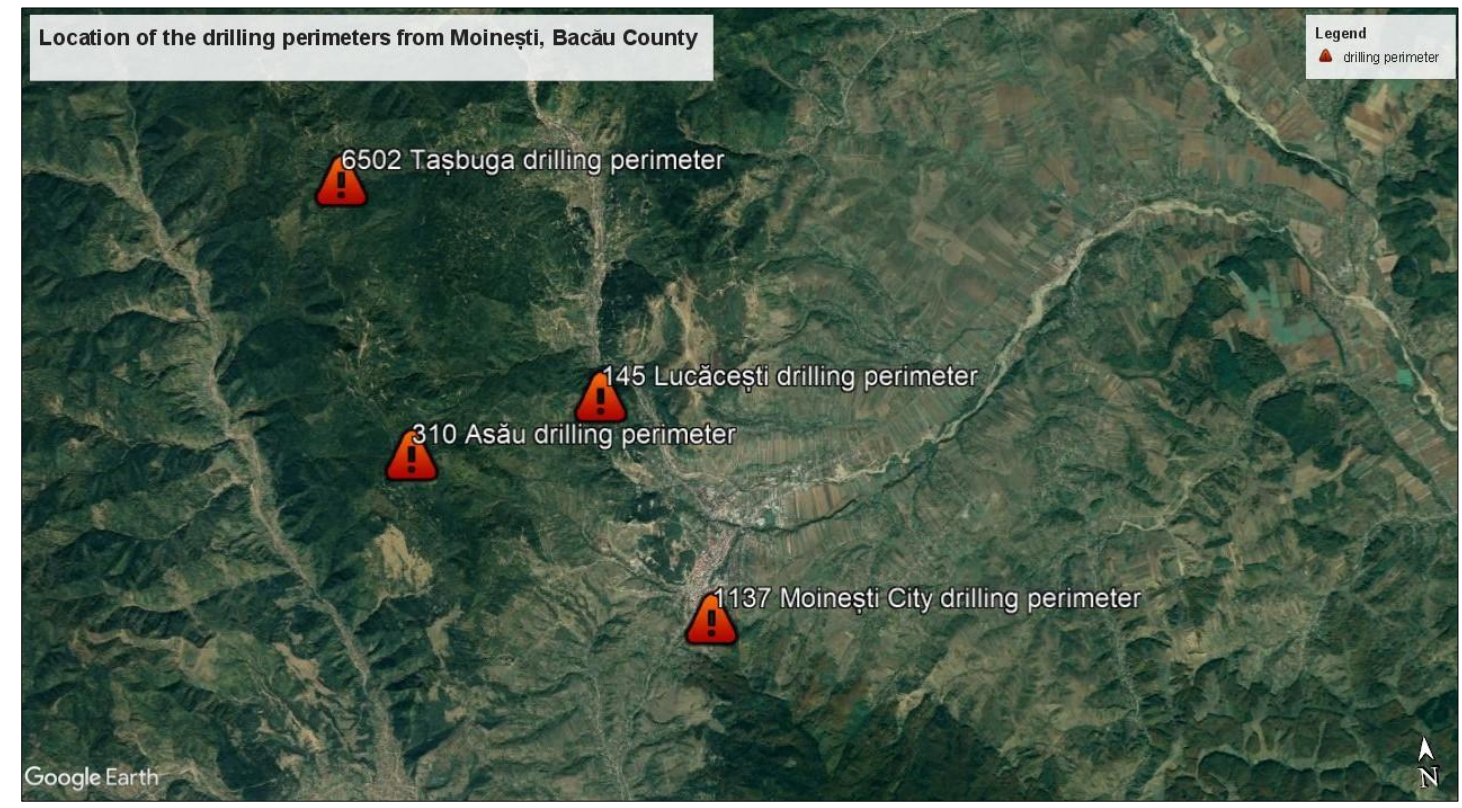

Figure 1. The location of the fields

The following methods were used for determining the soil's chemical and physical parameters:

- $p H$ was determined in a watery soil suspension, by measuring potentiometrically the concentration of hydrogen ions;

- $\quad$ humus content was determined through the Schollenberger method;

- alkaline-earth carbonates content was determined though the gasometrical method;

- changeable hydrogen (hydrolytic acidity- SH) was determined by the Kappen method;

- the sum of interchangeable cations, or the sum of exchange basis (SB) was determined by replacing them in soil with a acetate ammonium solution; cations $\left(\mathrm{Ca}^{+}, \mathrm{Na}^{+}, \mathrm{Mg}^{+}, \mathrm{K}^{+}\right)$are read with the atomic absorption spectrophotometer;

- total cationic exchange capacity (T) is obtained by adding SH and SB;

- the degree of base saturation (V) represents the soil's debasification level;

- total nitrogen content was determined by the Kjeldhal method;

- the colloidal complex composed mobile phosphorus and mobile potassium was obtained from the infusion of an ammonium lactate solution collided with acetic acid (ALA);

- soil texture was determined through the strainer and dropper methods, with the separation of granulometric fractions (sand, dust, clay).

Furthermore, two different soil samples from the depth of up to $30 \mathrm{~cm}$ and $31-60 \mathrm{~cm}$ were extracted from all soil profiles in order to determine the content of oil residues (hydrocarbons) [18]. These were introduced in special containers and kept at a low temperature for avoiding the emission of chemical compounds present in the hydrocarbon's structure. The samples were analyzed in the laboratory from the Technological Research and Design Institute (ICPT) Câmpina. Here, the content of oil hydrocarbons was determined (TPH - total petroleum hydrocarbons) through the FT-IR spectrometry. The TPH values expressed in $\mathrm{mg} / \mathrm{kg}$ were compared with reference values [19] in order to determine if the current content is situated with the admissible limits regarding sensible usages (including forests) and if it allows the reinstallation of forest vegetation.

\section{Results and discussions}

\subsection{Results}

The results obtained after performing laboratory analyzes are presented in Tables 1-3.

As such, the clay content ranges between 9.13 and $41.47 \%$ in the $0-20 \mathrm{~cm}$ soil layer and between 13.43 and $56.35 \% 20$ and $40 \mathrm{~cm}$ in drill square. In Table 1, considerable variations are registered for the 
same profile (P2, 145 Lucăcești drill), while the clay content is higher $(41.47 \%)$ in the superior layer and lower $(24.77 \%)$ in the subjacent one (P1, 310 Asau drill). In the soils from neighboring forests (unaffected by oil exploitation), the clay content is ranging between 10.65 and $23.95 \%$ in the surface horizons and between 17.47 and $22.82 \%$ in the following horizons.

Table 1 - Results of the soil's physical analyses

\begin{tabular}{|c|c|c|c|c|c|c|c|}
\hline \multirow{2}{*}{ Nr. drill name } & \multirow{2}{*}{$\begin{array}{c}\text { Occupied } \\
\text { surface }\left(\mathbf{m}^{2}\right)\end{array}$} & \multirow{2}{*}{$\begin{array}{l}\text { Location, } \\
\text { Forest District, } \\
\text { UP/ Parcel }\end{array}$} & \multirow{2}{*}{$\begin{array}{c}\text { Soil } \\
\text { profile }\end{array}$} & \multirow{2}{*}{$\begin{array}{c}\text { Sample } \\
\text { depth }(\mathrm{cm})\end{array}$} & \multicolumn{3}{|c|}{ Content (\%) of ... } \\
\hline & & & & & Sand & Dust & Clay \\
\hline \multirow{8}{*}{6502 Taşbuga } & \multirow{8}{*}{20.024} & \multirow{8}{*}{$\begin{array}{l}\text { OS Moineşti, } \\
\text { UP I, u.a. 153M }\end{array}$} & \multirow{4}{*}{$\mathrm{P} 1$} & $0-18$ & 50.820 & 29.992 & 19.188 \\
\hline & & & & $18-38$ & 49.083 & 32.328 & 18.589 \\
\hline & & & & $38-60$ & 46.173 & 33.656 & 20.172 \\
\hline & & & & $60-80$ & 47.005 & 32.371 & 20.624 \\
\hline & & & \multirow{2}{*}{$\mathrm{P} 4$} & $0-15$ & 54.914 & 35.956 & 9.129 \\
\hline & & & & $16-40$ & 67.049 & 19.525 & 13.426 \\
\hline & & & \multirow{2}{*}{ P5M } & $0-20$ & 46.520 & 29.531 & 23.948 \\
\hline & & & & $21-40$ & 51.907 & 27.093 & 21.000 \\
\hline \multirow{3}{*}{145 Lucăcești } & \multirow{3}{*}{1.000} & \multirow{3}{*}{$\begin{array}{l}\text { OS Moineşti, } \\
\text { UP I, u.a. } 26 \mathrm{M}_{1}\end{array}$} & \multirow{3}{*}{$\mathrm{P} 2$} & $0-15$ & 40.596 & 37.203 & 22.200 \\
\hline & & & & $16-40$ & 7.378 & 36.269 & 56.352 \\
\hline & & & & $41-60$ & 13.840 & 36.224 & 49.936 \\
\hline \multirow{4}{*}{310 Asău } & \multirow{4}{*}{2.447} & \multirow{4}{*}{$\begin{array}{l}\text { OS Comăneşti, } \\
\text { UP VIII, u.a. } \\
\text { 95B }\end{array}$} & \multirow{2}{*}{$\mathrm{P} 1$} & $0-17$ & 14.716 & 43.815 & 41.469 \\
\hline & & & & $18-50$ & 49.431 & 25.794 & 24.775 \\
\hline & & & \multirow{2}{*}{$\mathrm{P} 2 \mathrm{M}$} & $0-18$ & 68.538 & 20.810 & 10.652 \\
\hline & & & & $19-42$ & 72.733 & 9.796 & 17.471 \\
\hline \multirow{5}{*}{1137 Moineşti } & \multirow{5}{*}{1.039} & \multirow{5}{*}{$\begin{array}{l}\text { OS Dărmăneşti, } \\
\text { UP VIII, u.a. } \\
\text { 2F }\end{array}$} & \multirow{3}{*}{$\mathrm{P} 1$} & $0-20$ & 45.376 & 24.405 & 30.219 \\
\hline & & & & $20-50$ & 43.453 & 23.906 & 32.640 \\
\hline & & & & $51-70$ & 48.359 & 26.212 & 25.428 \\
\hline & & & \multirow[b]{2}{*}{$\mathrm{P} 2 \mathrm{M}$} & $0-24$ & 44.028 & 42.392 & 13.581 \\
\hline & & & & $24-60$ & 66.892 & 10.293 & 22.815 \\
\hline
\end{tabular}

Results of the soil's chemical analyses (Table 2) show that, the humus content (Ht) is very small up to medium in all the analyzed soil profiles, ranging between $0.57-4.53 \%$ in superior layers $(0-20 \mathrm{~cm})$ and between $0.62-5.22 \%$ in layers from 20 up to $50 \mathrm{~cm}$; sometimes, humus content is rather high even at depths larger than $50 \mathrm{~cm}(3.59 \%)$ even though it is much lower in superior layers $(1.97-2.42 \%$; P1, 1137 Moinesti drill). In forest soils humus content per profile is ranging between $1.19-3.65 \%$ in the first $20-25 \mathrm{~cm}$ and $1.3-4.3 \%$ in the following horizons.

Total nitrogen content also varies, being in general small or very small and ranging between 0.028 $0.196 \mathrm{mg} / 100 \mathrm{~g}$ soil, in the first layer $(20-25 \mathrm{~cm}$ ) and decreasing (up to $0.168 \mathrm{mg} / 100 \mathrm{~g}$ soil) in the following layer; in forest soils nitrogen content increases up to $0.252 \mathrm{mg} / 100 \mathrm{~g}$ soil.

The content of mobile phosphorus (Pm) varies from 0.25 (extremely low) up to 8.07 (extremely high) in the superior horizon and between 0.19 (extremely low) and $12.1 \mathrm{mg} / 100 \mathrm{~g}$ soil (very high) in in the following horizon $(20-50 \mathrm{~cm})$; the phosphorus content is more balanced in forest soils, ranging between 0.64 (very small) and $2.83 \mathrm{mg} / 100 \mathrm{~g}$ soil (average), in A horizon $(0-20 \mathrm{~cm}$ ) and between 0.4 (very low) and $1.33 \mathrm{mg} / 100 \mathrm{~g}$ soil (low), in the following horizon (up to $40-60 \mathrm{~cm}$ ).

The potassium content (K) varies from 0.56 (extremely low) up to $5.14 \mathrm{mg} / 100 \mathrm{~g}$ soil (low) at the surface and from 0.53 (extremely low) and $3.07 \mathrm{mg} / 100 \mathrm{~g}$ soil (very low) in depth; in soils from neighboring forests, the potassium content ranges between 0.72 (extremely low) and $7.98 \mathrm{mg} / 100 \mathrm{~g}$ soil (low).

The $p \mathrm{H}$ values are situated between $7.14-8.28$ in the superior horizon $(0-24 \mathrm{~cm})$ and between 6.88 -8.03 in the following horizon; in only one profile (P3, 310 Asău drill) is the soil weakly acid at the surface $(p \mathrm{H} \mathrm{5.96)}$ towards strongly acid in depth $(p \mathrm{H} 4.8)$. This situation was encountered on the access road towards the drill, representing a blunted soil with a compact and leveled field (uncovered from the soil layer).The $p \mathrm{H}$ ranges between 5.14 and 6.3 in the superior horizon $(0-20 \mathrm{~cm})$ and between 5.24 and 6.15 in the following horizon for the soils recolted from the forest. In only one soil profile (P2M, 1137 Moineşti drill), a very strong acid soil reaction was encountered ( $p \mathrm{H}$ ranged between 4.1 and 4.3). 
The content of calcium carbonates $\left(\mathrm{CO}_{3} \mathrm{Ca}\right)$ is very low towards low $(<4 \%)$, suggesting uncarbonated or weakly carbonated soils in most situations. The values are moderate $(11.4 \%$ - carbonate soil) in the superior part of a single soil profile (P2-145 Lucăceşti drill); forest soils do not contain calcium carbonates.

Table 2. Results of the soil's chemical analyses

\begin{tabular}{|c|c|c|c|c|c|c|c|c|c|c|c|c|c|}
\hline Drill name & $\begin{array}{l}\text { Soil } \\
\text { prof } \\
\text { ile }\end{array}$ & $\begin{array}{l}\text { Depth } \\
\text { cm }\end{array}$ & pH & $\begin{array}{c}\text { Carbo } \\
\text {-nates } \\
\%\end{array}$ & $\begin{array}{c}\mathrm{Ht} \\
\%\end{array}$ & $\begin{array}{l}\mathrm{Nt} \\
\%\end{array}$ & $\begin{array}{c}\text { Pm } \\
\mathrm{mg} / 100 \mathrm{~g}\end{array}$ & $\begin{array}{c}\mathrm{Km} \\
\mathrm{mg} / 100 \mathrm{~g}\end{array}$ & $\begin{array}{c}\text { Soluble } \\
\text { salts } \\
\text { mg/100g }\end{array}$ & $\begin{array}{c}\text { SH } \\
\text { me/100g }\end{array}$ & $\begin{array}{c}\text { SB } \\
\text { me/100g }\end{array}$ & $\mathbf{T}$ & $\begin{array}{l}\mathrm{V} \\
\%\end{array}$ \\
\hline \multirow{11}{*}{$\begin{array}{c}6502 \\
\text { Taşbuga }\end{array}$} & \multirow{4}{*}{$\mathrm{P} 1$} & $0-18$ & 8.28 & 0.0 & 1.20 & 0.084 & 0.38 & 0.76 & 51.00 & & & & \\
\hline & & $18-38$ & 7.80 & 0.0 & 1.79 & 0.112 & 0.49 & 1.76 & 62.56 & & & & \\
\hline & & $38-60$ & 6.35 & & 1.44 & 0.112 & 0.71 & 2.12 & & 4.50 & 9.31 & 13.81 & 67.42 \\
\hline & & $60-80$ & 6.18 & & 1.32 & 0.056 & 0.72 & 2.35 & & 5.84 & 9.18 & 15.02 & 61.12 \\
\hline & \multirow{3}{*}{$\mathrm{P} 2$} & $0-18$ & 7.92 & 0.8 & 4.09 & 0.140 & 2.02 & 2.33 & 55.29 & & & & \\
\hline & & $19-50$ & 7.99 & 2.5 & 5.22 & 0.168 & 1.31 & 3.06 & 65.28 & & & & \\
\hline & & $50-60$ & 8.18 & 3.0 & 2.96 & 0.084 & 1.26 & 2.23 & 65.05 & & & & \\
\hline & \multirow{2}{*}{$\mathrm{P} 4$} & $0-15$ & 7.20 & 0.2 & 4.53 & 0.168 & 1.71 & 1.53 & 34.48 & & & & \\
\hline & & $16-40$ & 7.97 & 0.5 & 1.64 & 0.056 & 1.60 & 0.53 & 40.57 & & & & \\
\hline & \multirow[b]{2}{*}{ P5M } & $0-20$ & 5.88 & & 3.65 & 0.168 & 0.86 & 1.03 & & 7.02 & 13.87 & 20.89 & 66.39 \\
\hline & & $21-40$ & 5.95 & & 2.45 & 0.140 & 0.81 & 0.83 & & 5.09 & 12.87 & 17.96 & 71.66 \\
\hline \multirow{8}{*}{$\begin{array}{c}145 \\
\text { Lucăcești }\end{array}$} & \multirow{2}{*}{$\mathrm{P} 1$} & $0-20$ & 8.06 & 0.4 & 1.9 & 0.084 & 0.25 & 0.56 & 57.06 & & & & \\
\hline & & $43-70$ & 6.38 & & 0.27 & 0.028 & 1.54 & 0.01 & & 3.38 & 9.2 & 12.58 & 73.14 \\
\hline & \multirow{3}{*}{$\mathrm{P} 2$} & $0-15$ & 8.12 & 11.4 & 1.77 & 0.196 & 2.31 & 5.14 & 66.75 & & & & \\
\hline & & $16-40$ & 7.13 & 0.4 & 1.54 & 0.084 & 0.19 & 3.07 & 93.5 & & & & \\
\hline & & $41-60$ & 7.68 & 0 & 1.34 & 0.112 & 0.15 & 3.67 & 63.24 & & & & \\
\hline & \multirow{3}{*}{ P3M } & $0-22$ & 5.14 & & 2.81 & 0.14 & 0.64 & 7.98 & & 8.89 & 12.6 & 21.49 & 58.63 \\
\hline & & $23-50$ & 5.24 & & 4.3 & 0.252 & 1.04 & 3.97 & & 9.74 & 14.92 & 24.66 & 60.51 \\
\hline & & $51-70$ & 5.02 & & 1.92 & 0.112 & 0.33 & 2.62 & & 9.58 & 10.37 & 19.95 & 51.98 \\
\hline \multirow{6}{*}{310 Asău } & \multirow{2}{*}{$\mathrm{P} 1$} & $0-17$ & 7.14 & 0 & 3.87 & 0.168 & 3.39 & 2.48 & 34.65 & & & & \\
\hline & & $18-50$ & 8.03 & 0.4 & 2.65 & 0.084 & 1.31 & 1.87 & 76.84 & & & & \\
\hline & \multirow{2}{*}{ P3 } & $0-30$ & 5.96 & & 0.57 & 0.028 & 0.26 & 0.06 & & 3.91 & 5 & 8.91 & 56.11 \\
\hline & & $30-45$ & 4.8 & & 0.62 & 0.056 & 0.07 & 2.3 & & 10.82 & 4.37 & 15.19 & 28.77 \\
\hline & \multirow{2}{*}{$\mathrm{P} 2 \mathrm{M}$} & $0-18$ & 6.3 & & 1.85 & 0,028 & 0,87 & 0,72 & & 2.84 & 6,87 & 9,71 & 70.74 \\
\hline & & $19-42$ & 6.15 & & 1.65 & 0.028 & 0.4 & 0.09 & & 4.07 & 5.32 & 9.39 & 56.66 \\
\hline \multirow{4}{*}{$\begin{array}{c}1137 \\
\text { Moineşti }\end{array}$} & \multirow{3}{*}{$\mathrm{P} 1$} & $0-20$ & 7.6 & 0.5 & 2.42 & 0.084 & 8.07 & 2.61 & 47.77 & & & & \\
\hline & & $20-50$ & 7.72 & 0.2 & 1.97 & 0.084 & 12.1 & 2.64 & 50.19 & & & & \\
\hline & & $51-70$ & 7.74 & 0.5 & 3.59 & 0.14 & 3.5 & 2.64 & 66.98 & & & & \\
\hline & $\mathrm{P} 2 \mathrm{M}$ & $61-110$ & 4.3 & & 0.5 & 0.028 & 3.43 & 1.47 & & 11.46 & 3.04 & 14.5 & 20.98 \\
\hline
\end{tabular}

Soluble salts are presented in different concentrations (between 34.65 and $93.5 \mathrm{mg} / 100 \mathrm{~g}$ soil) that are higher in depth; according to STRS, 2012 [23], the soil is weakly salinized, values under $100 \mathrm{mg} / 100$ $\mathrm{g}$ soil being considered as admissible for forest vegetation. The total cationic exchange capacity (T) is low due to the reduced content of exchange bases ( $\mathrm{Sb}$ is very low to low, with values ranging between 4.37 and $12.01 \mathrm{me} / 100 \mathrm{~g}$ soil in the oil bore and between 5.32 and $14.92 \mathrm{me} / 100 \mathrm{~g}$ sol); as for the degree of saturation in basis (V), both oil bore soils as well as forest soils are mesobasic (V between 56-75\%) or oligo-mesobasic (V between 31 and 55\%). Low $\mathrm{V}$ values indicate soil acidification and its depletion in basic cations [22].

Table 3. Results of the soil's TPH analyses

\begin{tabular}{|c|c|c|c|}
\hline \multirow{2}{*}{ Name / drill name } & \multirow{2}{*}{$\begin{array}{c}\text { Soil } \\
\text { profile }\end{array}$} & \multicolumn{2}{|c|}{ TPH $(\mathrm{mg} / \mathrm{kg})$ and depth $(\mathrm{cm})$} \\
\hline & & $0-30$ & $30-60$ \\
\hline \multirow{3}{*}{6502 Taşbuga } & P1 & 180 & $<85$ \\
\hline & $\mathrm{P} 2$ & 2780 & 3630 \\
\hline & P4 & 930 & 760 \\
\hline \multirow{2}{*}{145 Lucăcești } & P1 & 126 & $<85$ \\
\hline & $\mathrm{P} 2$ & $<85$ & $<85$ \\
\hline \multirow{2}{*}{310 Asău } & $\mathrm{P} 1$ & 1970 & 2900 \\
\hline & $\mathrm{P} 2$ & 190 & $<85$ \\
\hline 1137 Moinesti & $\mathrm{P} 1$ & 264 & 140 \\
\hline
\end{tabular}


The analysis of oil hydrocarbons content (TPH) is presented in Table 3 being extracted from the soils of fields occupied by oil drills, which has emphasized the fact that, in most situations, the soil is polluted with oil hydrocarbons both in the superior part $(0-30 \mathrm{~cm})$ as well as in depth (between 30-60 cm). This pollution has resulted from oil extraction activities as well as from the leakage of oil residues. TPH values $<85 \mathrm{mg} / \mathrm{kg}$ soil are considered admissible for forest vegetation (sensible usages).

Four types of values were obtained for the analyzed situations, based on the TPH analysis [19]: warning values for sensible usages (between 100 and $200 \mathrm{mg} / \mathrm{kg}$ ); warning values for less sensible usages (between 200-1000 mg/kg); intervention values for sensible usages (between 1000 and 2000 $\mathrm{mg} / \mathrm{kg}$ ); intervention values for less sensible usages (over $2000 \mathrm{mg} / \mathrm{kg}$ soil).

With the exception of a soil profile (P2-Lucăcești, located on the access road), all analyzed profiles have recorded TPH values over the admissible limit $(85 \mathrm{mg} / \mathrm{kg})$, ranging between 126 and $3630 \mathrm{mg} / \mathrm{kg}$ soil. As such, they are situated within the warning values for sensible usages and surpass the threshold of intervention values for less sensible usages $(>2000 \mathrm{mg} / \mathrm{kg})$.

\subsection{Discussions}

The field observations and physico-chemical analyses (including the TPH analysis) have established if the soil is capable to sustain a forest culture through its present complex of nutritive and mineral elements (humus, N, P, K etc.) or if the content of dangerous substances exceeds the limits admissible for forest vegetation. In addition, the analysis focused on determining if the soil has suffered composition or structure changes in comparison with the soil located in the neighboring forest (witness profile). Based on the obtained results, the necessary decontamination and silvo-ameliorative measures can be established and applied. Forest soils showcase a more balanced humus content (low up to average) per profile, emphasizing a better supply of nutritive substances.

Fields from afforested areas occupied by oil bores were strongly affected by the oil exploitation activity as well as by other activities realized during the exploitation period (transport, circulation of machines etc.). As such, the fields were both degraded and polluted.

The impact was mainly caused by the following activities [21]: site creation, machine and material transport; drilling, levelling the bore, pushing the soil layers outside the activity area; discharging / accidental leakage of substances used in the drilling activity: salted water, bentonite, extraction mud, raw oil etc.; uncovering the polluted soil layer (after abandoning the drills) and covering it with soil originating from other areas (mixture of soil and rock).

The identified anthropic degradation processes are: strong soil consolidation (especially on access roads) and starting even in the first horizons; truncation and/or derangement/mixture of soil or soil layers with rocks; oil residue pollution, soil salinization and/or soil argilization. The type of land degradation was established based on the site-mapping using the unitary site-mapping method of degraded lands [9] taking into account the characteristics of the land and soil. Such degradation processes frequently occur in areas with mining or oil exploitation where various excavations are carried out that lead to soil disturbance.

In general, the soils of the studied lands are weakly profound $(50-70 \mathrm{~cm})$, compact, represented by a mixture of soil and rock (sandstone) and have a high skeleton content (25-60\%), even at the surface. This emphasizes the soil's uncovering or the soils' layers derangement and the coverage of genetic horizons with different soil materials mixed with rocks. Normally, the clay content increases in depth. In certain situations, excessive loaming ( $56.35 \%$ clay content) was caused by venting drill mud with a high content of bentonite, used in the oil extraction process. In the soils from neighboring forests (unaffected by oil exploitation), the clay content is more uniform on the profile and much reduced (max. 23.95\%). The high clay content is a limitative ecological factor for the majority of forest species, favoring pseudo-gleying processes or a strong soil densification with negative effects in the plant's nutrition or water absorption processes.

The soils' texture is clayish-sandy up to clayish-loamy or clayish-dusty. This situation appears because the soils have a clay, dust and sand content that varies from one profile to the other and even in 
the same profile, a fact that emphasizes the different nature of soil layers in mixture with rocks as shown in Table 1. The content of nutritive elements from Table 2 varies from one profile to another and from one horizon to another, registering sometimes higher values in the intermediary or inferior horizons. This emphasizes the characteristics of a soil with mixed layers of different origins. Forest soils showcase a more balanced humus content (low up to average) per profile, emphasizing a better supply of nutritive substances.

Regarding on soil reaction, this is neutral towards weakly alkaline in the majority of situations encountered in the fields occupied by drills. The soils from neighboring forests have in general a moderately acid towards weakly alkaline reaction. The $p \mathrm{H}$ parameter highlights the fact that the soil from the oil bores is a different soil from the local one.

Soluble salts are present in the majority of soil profiles from the analyzed oil bores. In the case of forest soils, the analyses have emphasized the lack of soluble salts, leading to the conclusion that salts originate in oil bores from the salted water used in the oil extraction process.

The presence of oil residues has lead to the modification of the soil's physical and chemical properties by decreasing the complex of nutritive elements $(\mathrm{N}, \mathrm{P}, \mathrm{K})$, by increasing $p \mathrm{H}$ and clay content and so on. As a consequence, the pollutant has accumulated at different depths, generating a deficit of mineral substances. This effect was caused by the field's plain configuration, the leakage and stagnation of some oil residues on long term and by the waterproof layer formed of oil compounds and extraction clay/mud. This was complemented by a decrease of carbon reserves and bacteria that favor nitrogen fixation processes in the plant's radicular system.

Through the effectuated observations and from the analyze of the factors that determine soil fertility, namely limitative edaphic factors (clay content, nutritive elements, salt content, soil reaction etc.) has framed these soils in the following soil class [22]: Antrisoils (ANT - unevolved soils, blunted or rutted), soil type: techno soil (TT) - resulted from human changes, soil subtype: copertic (TTct), polluted with oil residues. Soils from neighboring forests are situated in specific forest soil types and classes (Cambisoils). These soils are well structured, rich in nutritive elements and with a high useful water capacity, ensuring an increased fertility for local forests (mixtures of softwood and hardwood species). The respective lands are included in the category of anthropically degraded lands, respectively: lands uncovered by the soil layer and lands with muddy or disturbed soils, with soil mixture with rock [20].

The presence of pollutant concentrations in the soils of fields used in oil extraction requires informing the competent authorities about their potential impact on the environment as well as introducing additional monitoring and measures for reducing pollutant concentrations from emissions/evacuations [19]. In consequence, affected fields (polluted with oil extraction residues) do not fulfill the minimum conditions for afforestation and are not apt for installing forest vegetation. A series of special measures and works are necessary in order to render them back in the silvicultural circuit $[1,2,24]$. Based on their impaired/pollution degree, bio remedy techniques are recommended (for reducing toxicity/pollutant levels) or measures for eliminating the pollutant (decontamination), followed by pedo-ameliorative measures.

The bio remedy of soils contaminated with oil [11,25] is an efficient technique that is sage, economically feasible, environmentally friendly and a versatile or complementary alternative to physicochemical treatments. The procedure consists in: soil scarification (on all its compact surface) for stimulating the aero-hydric regime, administering amendments, organic (bio stimulation) and mineral fertilization (increasing nitrogen content for reducing the C:N ration), phyto-remedies through lucerne or mowing grass, applying absorbers (for the absorption and retention of oil residues).

Soil analyses will be repeated one year after applying the bio remedy or decontamination works. The analyses are necessary for measuring the physico-chemical properties and to ensure that the soil respects the ecological demands of forest species recommended for afforestation. 


\section{Conclusions}

The effects of oil extraction activities on soils consist in: a strong soil compaction (especially on access roads); truncation and/or derangement/mixture of soils or soil layers with rock; oil residue pollution, soil salinization and/or soil argilization.

The high or variable clay content from the fields utilised for petroleum exploitations, caused by oil $\mathrm{mud} /$ bentonite spillage or by the covering with soil originating from other areas, is a limitative ecological factor for the majority of forest species. This fact favors pseudo-gleisation processes or a strong soil compactness that leads to negative effects in the plant's nutritive or water absorption processes.

The reduced or variable content of nutritive elements per soil profile as well as the other physicalchemical properties, are determined by uncovering/covering, derangement, compactness or mixing soil horizons with rock.

In the case of oil bores, the content of soluble salts indicates that they originate from leakages of salted water used in the oil extraction process.

The content of oil hydrocarbons (TPH) exceeds the admissible limits and emphasize the fact that the soil is polluted with oil residues caused by the extraction activity or by the leakage of oil residues. The presence of these residues has led to the change of the soil physico-chemical properties by diminishing the complex of nutritive elements (nitrogen, phosphorus, potassium, etc.), increasing $p \mathrm{H}$ and the clay content. All these aspects lead to negative effects in the evolution of physiologic processes specific to plants.

The analyzed lands, anthropically degraded or polluted with oil, do not fulfill the minimum conditions for afforestation. However, they can be rendered back to the silvicultural circuit after applying bio remedy technologies or measures for eliminating the soil pollutant (decontamination methods) and pedo-ameliorative measures [1], in order to improve the chemical and physical parameters of the soils, as well as to satisfy the minimum requirements of some wood species.

Acknowledgments: The data were collected and processed between October 2019 - April 2020, within the elaboration of Pedostational Studies on the state of forest lands occupied by abandoned objectives (oil well) to be reintroduced in the forest area, within the service contract no. 99007515/2019 for OMV - Petrom.

\section{References}

1. ***NATIONAL INSTITUTE FOR RESEARCH AND DEVELOPMENT IN FORESTRY (INCDS) "MARIN DRĂCEA",2020, Pedostational studies regarding the state of the lands for abandoned objectives (wells) in order to be reintroduced in the forest fund, Service contract no. 99007515/2019 OMV - Petrom (INCDS archive).

2. CONSTANDACHE, C., DINCĂ, L., TUDOR, C., ONET, C., The ecological reconstruction of forest ecosystems affected by landslides, Natural Resources and Sustainable Development, 9, 2019, 144-159. 3.POTRA, A.F., Evaluarea calităţii solurilor în zona carbochim Cluj-Napoca în vederea remedierii, Analele Universităţii “Constantin Brâncuşi” din Târgu Jiu, Seria Inginerie, nr. 3, 2011.

4. MENDES DA SILVA, E., CAMPOS PESO-AGUIAR, M., TEIXEIRA NAVARRO, M.D.F., Impact of petroleum pollution on aquatic coastal ecosystems in Brazil, Environmental Toxicology and Chemistry, 16 (1), 1997, 112-118.

5.MARGESIN, R., SCHINNER, F., Biodegradation and bioremediation of hydrocarbons in extreme environments, Appl Microbiol Biotechnol, 56, 2001, 650-663.

6.IZDEBSKA-MUCHA, D., TRZCIŃSKI, J., Effects of petroleum pollution on clay soil microstructure, Geologija, 50, Supplement.P, 2008, 69-75.

7. ARELLANO, P., TANSEY, K., BALZTER, H., TELLKAMP, M., Plant Family-Specific Impacts of Petroleum Pollution on Biodiversity and Leaf Chlorophyll Content in the Amazon Rainforest of Ecuador, PLoSONE 12(1), 2017, e0169867. 
8. ȘOFLETEA, N., DINCĂ, L., SPÂRCHEZ, G., Methodology for determining the quality of the lands situated outside forest resources in the case of the main tree species cultivated in Romania, Bulletin of the Transilvania University of Brasov, Series II-Forestry, Wood Industry, Agricultural Food Engineering, 3(52), 2010, 91-98.

9. CIORTUZ, I., PĂCURAR, V.D., Ameliorații silvice, Ed. Lux Libris, Braşov, 2004, 231p.

10. POTRA, A.F., MICLE, V., BĂBUŢ, C.S., Studiu privind bioremedierea solurilor contaminate cu hidrocarburi petroliere, ECOTERRA - Journal of Environmental Research and Protection, no. 31, 2012, 68-73.

11. DUMITRU, M., SIMOTA, C., TOTI, M., MARIN, N., Reabilitarea solurilor poluate cu hidrocarburi petroliere, Ed. Terra Nostra Iasi, 2016, 400 pg.

12. CONSTANDACHE, C., PETICILA, A., DINCĂ, L., VASILE, D., The usage of Sea Buckthorn (Hippophae rhamnoides L.) for improving Romania's degraded lands, AgroLife Scientific Journal, 5(2), 2016, 50-58.

13. DINCĂ, L., HOLONEC, L., SOCACIU, C., DINULICĂ, F., CONSTANDACHE, C., BLAGA, T., PETICILĂ, A., Hipphophae Salicifolia D. Don - a miraculous species less known in Europe, Notulae Botanicae Horti Agrobotanici Cluj-Napoca, 46(2), 2018, 474-483.

14. ***ICAS, Amenajamente silvice, O.S. Moineşti, Comăneşti, Dărmăneşti, 2014, (arhiva INCDS).

15. DINCĂ, L., LUCACI, D., IACOBAN, C., IONESCU, M., Metode de analiză a proprietăţilor şi soluţiei solurilor, Editura Tehnică Silvică, Bucureşti, 2012, 173 pg.

16. CRIȘAN, V. E., DINCĂ, L.C., DECĂ, S.Ș., Analysis of chemical properties of forest soils from Bacau County, Rev. Chim., 71(4), 2020, 81-86.

17. EDU, E.M., UDRESCU, S., MIHALACHE, M., DINCĂ, L., Physical and chemical characterization of dystric cambisol from the Piatra Craiului National Park, Scientific papers Serie A Agonomy, 56, 2013, 37-39.

18.*** ICPA, Metodologia evaluării solurilor poluate (MESP), 1987.

19.***MAPPM, 1997, ORDIN nr. 756/1997, Pentru aprobarea reglementarii privind evaluarea poluării mediului.

20.***MAPPM, 2000, Norme tehnice privind compoziţii, scheme şi tehnologii de regenerare a pădurilor şi de împădurire a terenurilor degradate.

21. RUSĂI, L., Impactul exploatărilor petroliere asupra solurilor în zona Moinești, județul Bacău - Teză de doctorat - Rezumat, Universitatea "Vasile Alecsandri" din Bacău, România, 2018.

22. SPÂRCHEZ, G., TÂRZIU, D.R., DINCĂ, L., Pedologie, Ed. Lux Libris, Braşov, 2011, 293p.

23. FLOREA N., MUNTEANU I., Sistemul român de taxonomie a solurilor, Editura SITECH - Craiova, 2012.

24.CONSTANDACHE, C., NISTOR, S., Scientific Basis for Ecological Restoration of Degraded Lands, Proceedings of the Biennial International Symposium „Forest and sustainable development, Transilvania University Press, ISSN: 1843-505X, 2011, pp.147-153.

25.***ICPA, Tehnologie de bioremediere a solurilor poluate cu hidrocarburi petroliere, BIOPETROTEH PN-II-PT-PCCA-2013-4-0347, 2017.

Manuscript received: 3.11 .2020 